\title{
PEMBERDAYAAN MASYARAKAT MELALUI PENGEMBANGAN DESAIN PRODUK ANYAMAN MANSIANG DI JORONG TARATAK NAGARI KUBANG KECAMATAN GUGUAK, KABUPATEN LIMAPULUH KOTA
}

\section{COMMUNITY EMPOWERMENT THROUGH DEVELOPMENT OF MANSIANG WOVEN PRODUCT DESIGN IN JORONG TARATAK NAGARI KUBANG KECAMATAN GUGUAK, KABUPATEN LIMAPULUH KOTA}

\author{
${ }^{1)}$ Ahmad Bahrudin, ${ }^{2)}$ Widdiyanti, ${ }^{3)}$ Wahyono \\ ${ }^{1,2,3)}$ Program Studi Kriya Seni Fakultas Seni Rupa dan Desain \\ Institut Seni Indonesia Padangpanjang \\ Jln. Bahder Johan No. 35 Kota Padangpanjang, Sumatera Barat \\ Email: ahmadbahrudin@isi-padangpanjang.ac.id
}

\begin{abstract}
ABSTRAK
Kegiatan pemberdayaan masyarakat dilaksanakan di Nagari Kubang karena sebagian besar masyarakatnya, terutama para wanita, memiliki keterampilan menganyam batang mansiang untuk dijadikan produk yaitu kombuik yang berfungsi sebagai tempat beras yang digunakan ketika akan berkunjung ketempat kematian. Tetapi eterampilan ini didapatkan secara turun temurun sehingga produk yang dihasilkan masih meniru produk yang sudah ada. Pengrajin ini membutuhkan tambahan keterampilan lain, seperti cara mendesain aneka ragam bentuk produk olahan anyaman dan implementasi desain menjadi produk jadi. Metode kegiatan yang dilakukan adalah pendidikan masyarakat melalui kegiatan penyuluhan tentang pengembangan industri kreatif, pengembangan desain produk dan strategi produksi produk kerajinan mansiang. Metode pelatihan dilakukan melalui demonstrasi langsung diversifikasi produk kerajinan anyaman mansiang berdasar selera pasar. Adapun hasil dari kegiatan pengabdian ini adalah : 1) meningkatnya kemampuan pengajin dalam membuat desain, 2) produk-produk tas wanita dengan berbagai bentuk dengan bahan baku anyaman mansiang, 3) meningkatnya kemampuan dalam mengaplikasikan teknik hias decoupage dan sulam pita.
\end{abstract}

Kata kunci: Jorong taratak; Desain; Produk; Anyaman; Mansiang

\section{ABSTRACT}

Empowerment activities of MSME are carried out in Nagari Kubang because most of the community, especially women, have the skill of weaving Mansiang stems from being used as a product, which is a KOMBUIK which functions as a place of rice used when going to the location of death. But this skill is obtained from generation to generation so that the product produced still mimics existing products. These craftsmen need additional capabilities, such as how to design various forms of woven products and implement design into finished products. The method of activities undertaken is public education through counseling activities on the development of creative industries, the development of product designs, and production strategies for Mansiang handicraft products. The training method is carried out through a direct demonstration of Mansiang woven handicraft product diversification based on market tastes. The results of this dedication activity are: 1) increasing the ability of artisans in making designs, 2) products of women's bags with various shapes with Mansiang woven materials, 3) increasing ability to apply decoupage and ribbon embroidery techniques.

Keywords: Jorong taratak; Product; Design; Woven; Mansiang

Submitted : 15 Agustus 2019 Revision : 1 November 2019 Accepted : 17 Februari 2020 


\section{PENDAHULUAN}

Taratak sebuah nama jorong di Kenagarian Kubang, Kec.Guguak Kab.50 kota. Bila ditinjau dari segi mata pencarian, khususnya kaum ibu dan remaja putri, bahkan sebagian juga ada kaum bapak bekerja sebagai pengrajina nyaman mansiang yang disebut kombuik yang telah berkembang secara turun temurun. Bahkan ada suatu semboyan di kalangan masyarakat jorong Taratak "kalau wanita di jorong Taratak tidak pandai menganyam itu bukan orang Taratak".

Anyaman mansiang di jorong Taratak telah menjadi tulang punggung perekonomian masyarakat Taratak Kerajinan anyaman di Kenagarian Kubang merupakan usaha rumah tangga atau berkelompok yang pada awalnya rata-rata terdiri dari 5 orang ( Lita, Ma'ruf \& Surya, 2010). Kerajinan anyaman ini sebagian dikerjakan oleh kaum wanita (Ibu rumah tangga dan Remaja-remaja puteri). Usaha ini telah membudi daya di lingkungan masyarakat Taratak. Terutama kaum ibu baik tua maupun muda atau remaja putri juga anak-anak yang merupakan generasi penerus anyaman mansiang Taratak. Sepulang sekolah mereka membantu ibunya menganyam mansiang untuk mencari tambahan uang jajan. Bahkan juga ada ibu rumah tangga yang semata mengandalkan anyaman mansiang sebagai tulang punggung ekonominya, baik untuk memenuhi segala kebutuhan sehari-hari juga untuk biaya sekolah anaknya.

Pada proses penganyaman perajin tidak hanya menggunakan satu jenis teknik saja tetapi mengabungkan beberapa teknika nyaman disesuaikan dengan produk yang akan dibuat dan motif yang akan dihasilkan. Menurut Gerbono (2005) bahwa menganyam atau membuat nyaman adalah menyusun lusi dan pakan, lusi adalah: bagian iratan yang disusun membujur, sedangkan pakan adalah bagian iratan yang disusun melintang.

Bahan baku yang digunakan adalah sejenis tanaman mansiang, Dalam KBBI Mansiang adalah; Jenis rumput gelagah, sedangkan dalam website agrobisnis info:

Tanaman ini sering tumbuh dirawarawa atau sungai-sungai dangkal yang airnya tidak begitu deras. Tanaman Mansiang yang sering juga disebut dengan Wlingi atau Mendong adalah salah satu tumbuhan yang hidup di rawa, tanaman ini tumbuh di daerah yang berlumpur dan memiliki air yang cukup. Menurut (Purnomo \& Ferdianto, 2009). Mendong merupakan salah satu jenis rumput, dan bias anya tumbuh dengan panjang $\pm 100 \mathrm{~cm}$. (lihat gambar 1 ).

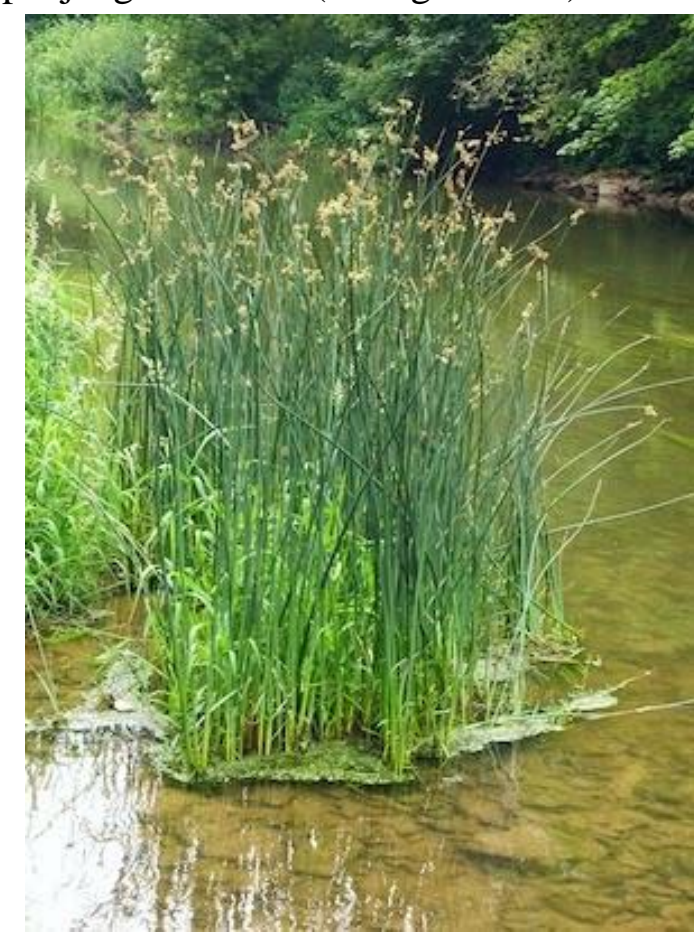

Gambar 1.Tanaman Mansiang (Sumber : Dokumentasi Widdiyanti 2016)

Masyarakat Taratak menyebutnya mansiang yang mana tanaman ini dibudidayakan disekitar tempat tinggal parapengrajin. Sedangkan hasil anyaman mansiang ini di sebut kombuik. Kegiatan perajin dalam menghasilkan kombuik sedangkan proses pewarnaan proses pewarnaan menggunakan bahan kimia dan menggunakan pewarna alam ( Prihatiningsih, 2013) dengan cara melakukan pencelupan pada pewarna yang telah di rebus, untuk selanjutnya melakukan pengeringan dengan cara di gantung dan diangin-anginkan

Adapun jenis dari kombuik ini juga bermacam-macam demikian juga kegunaannya. Pemasaran dari kombuik ini masyarakat Taratak menjualnya kepasar lokal dan regional. Sedangkan untuk pasar bertaraf nasional maupun internasional (produk anyaman mansiang (Kombuik) bisa di lihat pada gambar 2). 


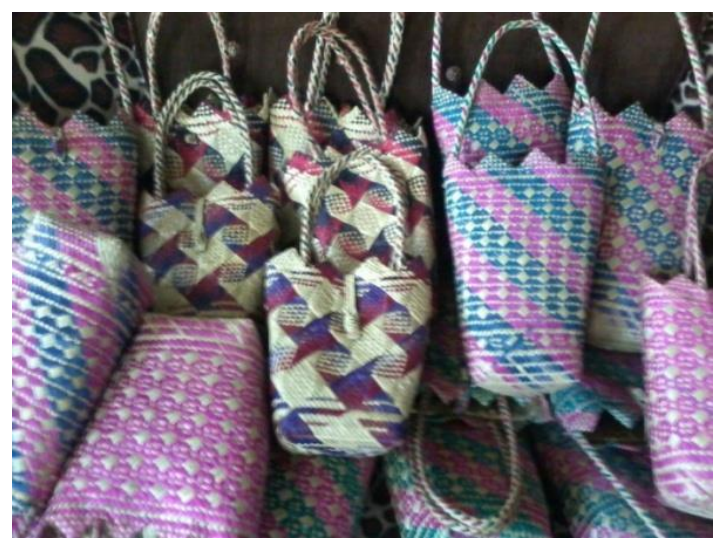

Gambar 2.Produk kombuik dengan bahan mansiang

(Foto.Widdiyanti 2016)

Melihat potensi tersebut di atas menghasilkan anyaman kombuik dengan bahan mansiang merupakan hasil Adat dan budaya lokal (Sugita, Priambadi, \& Suarnadwipa, 2016) belum begitu maksimal sebagai penghasilan pengrajin dalam memperoleh penghidupan yang layak, dalam aspek ekonomi kerajinan ini belum begitu menjanjikan, tetapi kemajuan Iptek yang sangat pesat perkembangannya bisa dimanfaatkan dalam pengembangan anyaman tersebut, saat ini keahlian menganyam masyarakat jorong taratak tidak diragukan lagi, tetapi dalam bidang lain seperti pengembangan desain produk masih sangat minim dan produk yang dibuatmasih bersifat pengulangan-pengulangan bentuk semata. Menurut Wahdah (2016) dengan bantuan pusat-pusat inovasi desain ini tentunya akan membantu proses pengembangan produk yang dilakukan oleh pengrajin. Untuk meningkatkan daya saing produk kerajinan, pemberdayaan dari segi aspek pelatihan kewirausahaan bagi pengrajin terutama untuk menumbuhkan jiwa berwirausaha bagi masyarakat perlu dilakukan. Dalam rangka mewujudkan beberapa hal yang telah disebutkan di atas, maka perlu memotivasi untuk membuat produk sesuai dengan selera pasar dengan cara melakukan pendampingan. Kegiatan menganyam terbebut membutuhkan sentuhan teknologi, serta pendekatan lainnya yang sesuai dengan kebutuhan pengrajin di jorong Taratak Nagari Kubang.

Berdasarkan beberapa permasalahan tersebut di atas, maka perlu untuk melakukan pemberdayaan masyarakat melalui program
Kuliah Kerja Nyata, dengan adanya kegiatan tersebut diharapkan dapat memecahkan masalah terutama dengan adanya beberapa mahasiswa yang memiliki bidang ilmu kekriyaan seperti kemampuan bidang ilmu tentang anyaman, pengembangan desain produk.

\section{METODE}

Kelompok masyarakat sasaran adalah UMKM perajin anyaman mansiang di jorong taratak nagari Kubang. Pemilihan kelompokmasyarakat perajin anyaman mansiang tersebut didasarkan pada pertimbangan banyaknya potensi sumber daya alam di daerah setempat terutama tanaman mansiang yang potensinya dapat terus dimanfaatkan dan dikembangkan menjadi industri kreatif yang menjanjikan. Metode kegiatan yang dilakukan adalah pendidikan masyarakat melalui kegiatan penyuluhan tentang pengembangan industri kreatif, melalui pengembangan desain produk dan strategi produksi produk kerajinan mansiang. Metode pelatihan berupa demonstrasi langsung atau praktik diversifikasi produk kerajinan anyaman mansiang berupa pengembangan desain produk yang berdasar pada selera pasar.

Pelatihan yang dipandu oleh narasumber (Mahasiswa dan Dosen) dan dibantu dengan seperangkat alat bantu untuk melakukan praktik secara langsung. Sebelum kegiatan pelatihan dilakukan terdapat beberapa hal kegiatan berupa persiapan yang perlu dilakukan.

\section{HASIL DAN PEMBAHASAN}

Hasil kegiatan yang telah dilaksanakan sesuai dengan tujuan yang telah ditetapkan dapat dijelaskan sebagai berikut:

\section{Pelatihan Pembuatan Desain Produk}

Dengan melihat potensi Jorong taratak yang memiliki kemampuan dalam membuat anyaman mansiang dan merupakan satusatunya sentra kerajinan yang berada di Sumatera Barat yang menghasilkan produk tersebut dititik beratkan pada pembuatan kriya fungsional menurut Bahrudin (2011) kriya dibagi menjadi empat bagian: Berdasarkan hal tersebut produk kriya dapat diklasifikasikan ke 
dalam empat kategori, yaitu: (1) Produk kriya tradisional yang berkonteks budaya, (2) Produk kriya yang berdasarkan pada konteks agama dan kepercayaan, (3) Produk kriya yang merupakan kerajinan rakyat, dan (4) Produk kriya yang dibuat oleh seniman dan disainer, adapun produk yang sudah dihasilkan yaitu kombuik (tempat membawa beras ketika akan melakukan takjiah) memiliki termasuk dalam kategori produk kriya tradisional dan konteks agama sebab produk tersebut digunakan pada kegiatan keagamaan, anyaman mansiang banyak peluang untuk dikembangkan menjadi industri kreatif berbasis potensi Jorong.

Hal ini juga didukung dengan sumberdaya manusia dimana umumnya penduduk Jorong tersebut berprofesi sebagai pengrajin anyaman mansiang, pada kegiatan tersebut para perajin anyaman mansiang diberi pemahaman tentang pentingnya pengembangan produk yang dihasilkan baik dari segi bentuknya maupun dari proses pembuatan produknya. Pada saat ini para perajin masih melakukan aktifitas pembuatan kerajinannya masih secara tradisional dan belum ada upaya untuk mengembangkan menjadi produk lain terutama pengembangan desainnya. Hal ini juga dijelaskan Sarno (2018), bahwa pengembangan industri kreatif dititik beratkan pada: (a) lapangan usaha kreatif dan budaya; (b) lapangan usaha kreatif atau (c) hak kekayaan intekektual. Pada kegiatan tersebut juga diketahui tentang bantuk produk yang dihasilkan belum beragam dan belum berdasar pada selesar pasar (market oriented).

Kegiatan pelatihan berupa penyuluhan potensi pengembangn desain supaya produk yang dihasilkan memiliki daya saing dengan produk sejenis yang dihasilkan oleh daerah lain. Menurut Susilo (2010) tentang daya saing, UMKM yang berdaya saing tinggi dicirikan oleh: (1) kecenderungan yang meningkat dari laju pertumbuhan volume produksi, (2) pangsa pasar domestik dan atau pasar ekspor yang selalu meningkat, (3) untuk pasar domestik, tidak hanya melayani pasar lokal saja tetapi juga nasional, dan (4) untuk pasar ekspor, tidak hanya melayani di satu negara tetapi juga banyak negara.adapun salah satu langkah supaya berdaya saing tinggi adalah dengan cara memberikan pemahaman tentang pentingnya pengembangan desain berdasarkan pada selera pasar dengan segmen yang jelas, yaitu memberikan stimulus dengan memberikan beberapa contoh baik gambar maupun produk acuan yang akan di jadikan sebagai ide penciptaan pada proses pengembangan desain, dalam hal ini adalah pengembangan desain produk. Menurut Bahrudin (2007), kata desain adalah sebuah model, pola konstruksi, ide dan rancangan produk baru yang belum ada sebelumnya atau lain daripada yang lain Menurut Sachari \& Sunarya (2000). Sejalan dengan itu, para kalangan insinyur menggunakan istilah rancang bangun, sebagai pengganti istilah desain,namun dikalangan keilmuan senirupa, istilah 'desain' tetap secara konsisten dan formal dipergunakan.hal itu ditindaklanjuti pada pembakuan nama program studi di perguruan tinggi, nama cabang ilmu, nama organisasi profesi, nama majalah, nama jurnal serta istilah yang dipergunakan pada beberapa undang-undang perlindungan intelektual.

Pengabdian ini menitik beratkan pada pelatihan desain mengajak para perajin anyaman masiang bisa menciptakan produk baru yang berpijak pada kegunaan/fungsi produk tersebut, dan untuk memberi keterampilan bagaimana cara mengembangkan desain maka perajin diberi pemahaman bagaimana cara mengembangkan desain tersebut, yangdibimbing oleh mahasiswa dan Dosen Pembimbing Lapangan, adapun tahapan-tahapannya adalah: (1). Eksplorasi bentuk dengan cara melihat produk yang sudah ada selanjutnya dikembangkan dan dituangkan dalam bentuk sketsa minimal tiga buah sketsa untuk masing-masing produk, (2). Seleksi sketsa yang telah dibuat dan di buat desainnya yang dilengkapi dengan ukuran, bahan yang dibutuhkan, teknik finishing dan penentuan harga jual.

Peserta pelatihan peningkatan kemampuan desain produk yang terdiri dari para pengrajin yang berada di Jorong taratak Nagari Kubang, juga ditambah dengan ibu-ibu PKK yang di koordinir langsung oleh ibu darwanita Jorong Taratak. Pelaksanaan Pelatihan Pengembangan Produk difokuskan pada pengembangan pembuatan tas wanita dengan bahan utama mansiang dan dikombinasikan dengan bahan dukung lainnya seperti spon, kain puring, benang jahit, kertas dan lain-lain, serta menggunakan alat bantu seperti gunting, pisau, penggaris, pensil, 
penghapus dan lain-lain sedangkan alat bantunya yaitu spray gun untuk finishing produk dan mesin jahit.

Adapun tahapan-tahapan yang telah dilaksanakan selama pelaksanaan Program KKN-PPM dengan penekanan pada pengembangan desain produk anyaman mansiang adalah sebagai berikut: 1) pengenalan cara menganalisis pasar dengan cara melakukan studi pasar yang berada di nagari kubang, hal ini untuk mengetahui kebutuhan produk apa saja yang dibutuhkan oleh konsumen selain produk kombuik yang selama ini telah dihasilkan oleh pengrajin tersebut, 2) menentukan segmen pengguna produk tersebut, apakah segmen anak-anak, ramaja maupun dewasa. 3) melakukan riset gambar dengan cara pembuatan sketsa berjumlah 3 buah per produk yang akan di buat, hal ini dilakukan untuk memberi alternatif bentuk pada tiap produk, selanjutnya melakukan seleksi sketsa yang telah dibuat berdasarkan beberapa pertimbangan dengan menganut kaidah pembuatan desain yaitu form follow function (bentuk mengikuti fungsi). Berdasarkan hal tersebut, maka sketsa yang dihasilkan diharapkan akan fungsional (function), nyaman digunakan (ergonomic), sesuai kebutuhan pasar (market oriented) dan memiliki daya saing baik secara kualitas maupun harga jualnya.

Pelatihan pembuatan sketsa dengan cara memberikan contoh langsung bagaimana membuat gambar cepat berdasarkan beberapa ide yang timbul berdasarkan hal-hal yang telah dijabarkan di atas, selanjutnya peserta pengabdian praktek langsung cara membuat sketsa dengan dibimbing langsung oleh mahasiswa KKN terutama mahasiswa dari prodi Seni Kriya, dan mahasiswa lainnya membantu untuk mengarahkan cara-cara membuat sketsa seperti yang terlihat pada gambar 3 :

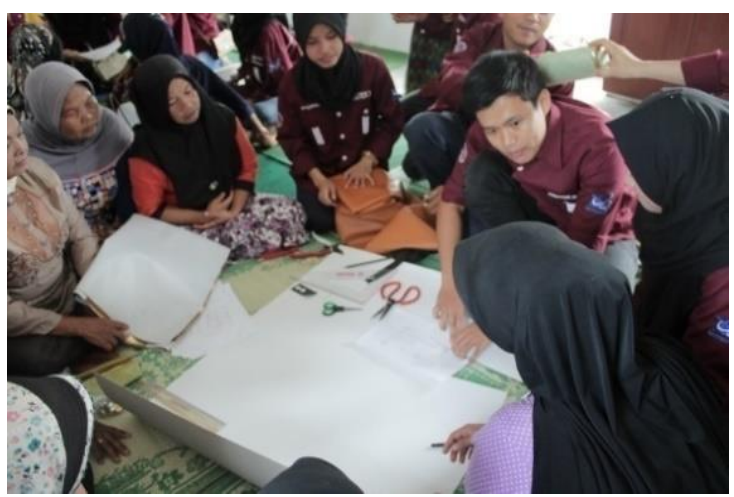

Gambar 3. Pelatihan pembuatan gambar desain (Sumber : dokumentasi tim Pengabdian 2017).

Memindahkan gambar sketsa ke kertas pola dengan skala 1:1 dengan menggunakan kertas dengan ketebalan 2 mmdanmelakukan. Pemotongan pola sesuai dengan gambar yang telah dibuat. Setelah pola di potong maka langkah selanjutnya adalah memberi tanda pada anyaman dengan menggunakan pola yang telah dibuat hal ini dilakukan untuk mempermudah dalam pemotongan bahan nantinya. Untuk memperkuat anyaman maka diberi pelapis berupa spon dengan ukuran $2 \mathrm{~mm}$, juga berfungsi untuk menambah ketebalan bidang anyaman juga sebagai penguat ketika diberikan beban nantinya.

\section{Implementasi Gambar Desain Produk}

Kegiatan pelatihan tersebut menitik beratkan pada cara implementasi desain dalam bentuk gambar menjadi produk jadi. Diawali dengan pentingnya pemahaman cara membaca gambar (desain) sehingga ke depannya produk dengan desain yang sama, siapapun perajinnya maka produk yang dihasilkan akan sama baik bentuk, warna, ukuran, maupun kualitasnya. Pada tahapan ini dilakukan pelatihan cara memotong pola dengan skala $1: 1$, memilih bahan sesuai dengan pola yang telah dibuat, setelah dipotong dilakukan penempelan anyaman pada spon sebagai penguat anyaman, dilanjutkan merakit bagian-bagian produk tersebut dengan cara di lemsedangkan untuk memperkuat dan memperindah sambungan maka dilakukan penjahitan. Pada pelatihan ini masih melakukan penjahitan manual dengan teknik jahit jelujur, sebab perajin belum ada keahlian menjahit menggunakan mesin jahit juga karena belum memiliki mesin jahit yang khusus untuk menjahit bahan tebal. 
Selain memberi pelatihan tentang pengembangan desain produk juga diberikan keterampilan tentang menghias produk dengan menggunakan dua jenis teknik hias yaitu teknik hias dengan decoupage. Menurut Murni, Hirdinis, \& Iqbal (2018) Decoupage membuat tampilan potongan-potongan kertas yang rata tampakdalam dan membuat pola serta gambar terlihat seolah-olah dilukis pada objek yang diproses, teknik decoupage menyenangkan dan mudah untuk mendekorasi objek apa saja, termasuk benda-benda di rumah, mulai dari vas kecil, tas hingga furnitur berukuran besar. Proses pelatihan decoupage diawali dengan memilih produk yang akan dihias, selanjutnya memotong kertas tissue yang berisi gambar diikuti dengan memberi lem PvaC pada produk. Setelah itu di tempel kertas yang telah dipotong tadi, untuk memperkuat maka digunakan top coat yang berfungsi sebagai pelapis yang berguna untuk melindungi produk tersebut dan akan menimbulkan kesan kilat pada produk tersebut.

Pelatihan teknik hias selanjutnya yaitu pengaplikasian tekni sulam pita, sulam pita biasanya diaplikasikan pada kain. Menurut Elvina, Efi \&Namira (2018) sulaman pita adalah salah satu teknik menghias kain dengan caramenjahitkan pita secara dekoratif diatas benda yang akan dihias, sehingga terbentuk desain hiasan baru dengan menggunakan berbagai macam-macam tusuk hias. Hal ini sesuai dengan pendapat Izzati (2012), bahwa sulam pita adalah teknik menghias kain dengan cara menjahit pita secara dekoratif diatas benda yang akan dihias, sehingga terbentuk desain hiasan baru menggunakan berbagai macammacam tusuk hias". Sedangkan sulam pita menurut Sugita et al., (2016) merupakan sulaman yang menggunakan bahan pita untuk menyulam. Pita yang digunakan biasanya pita organdi dan satin yang memiiki variasi warna dan ukuran. Sedangkan menurut menurut Elvina, Efi \& Namira (2018) sulaman pita memiliki kelebihan diantaranya (1) ornamen dengan sulam pita memberikan efek 3 dimensi, (2) warna tegas dan berani menjadikannya tanpak menonjol sebagai pusat perhatian pada bahan dasarnya, (3) pita beraneka ragam baik dari jenis bahan yang digunakan, segi ukuran, maupun warnanya sangat bervariasi.
Biasanya sulam pita diaplikasikan pada kain tetapi pada pelatihan ini sulam pita diaplikasikan pada produk anyaman mansiang. Diharapkan akan menambah nilai estetis sebab bahan yang digunakan sebagai bahan dasar produk tersebut yaitu anyaman polos.

Diharapkan dengan adanya pelatihan menyulam pita pada produk anyaman ini akan menambah nilai keindahan pada produk tersebut pada akhirnya akan meningkatkan nilai jual dan peningkatan penghasilan pengrajin anyaman mansiang di Jorong Taratak.

Setelah dilakukan pelatihan pembuatan desain dari mulai mencari ide, implementasi gagasan dalam bentuk sketsa, dilanjutkan dengan pembuatan desain produk, maka dapat disumpulkan dari peserta sebanyak 25 orang, ada 10 orang yang telah memiliki kemampuan mendesain. Diharapkan kedepannya peserta yang telah memiliki kemampuan desain tersebut dapat mengembangkan desain produk anyaman mansiang sesuai dengan selera pasar, sedangkan sisanya menjadi tim produksi. Adapun yang menjadi fokus dalam pelatihan ini adalah pembuatan desain tas wanita, dengan berbagai fungsi dan bentuk juga dengan teknik pengerjaan yang berbeda pula, selama pelaksanaan pengabdian telah di buat 5 bentuk model tas wanita.

\section{SIMPULAN}

Pelaksanaan program mampu menghasilkan luaran-luaran yang diharapkan sesuai dengan perencanaan di awal, peserta pelatihan memperoleh pengetahuan dan keterampilan yang akan menjadi bekal dalam pembuatan produk anyaman ke depannya.

\section{DAFTAR PUSTAKA}

Bahrudin, A. (2007). Desain Kriya II. (R. Zam, Ed.) (1st ed.). Padangpanjang: STSI Padangpanjang. Retrieved from isipadangpanjang.ac.id

Bahrudin, A. (2011). Kriya Seni Kelahiran dan Eksistensinya. Ekspresi Seni, 13 (1), 3645.

Prihatiningsih, B., (2013). Pengaruh Jumlah Limbah Daun Kupu-Kupu Terhadap Hasil Jadi Pewarnaan Mendong. E Journal Unesa, 02(1), 116-121.

Elvina, E., Efi, A., Nelmira. W., (2018). 
Pengembangan Bahan Ajar Sulaman Pita Mata Kuliah Menghias Busana Mahasiswa Ilmu Kesejahteraan Keluarga. E-Journal Home Economic and Tourism, $16(1), 1-16$.

Gerbono, A. S. D. (2005). Aneka Anyaman Bambu (2nd ed.). Yogyakarta: Kanisius. Retrieved from www.kanisiusmedia.com

Izzati, N. (2012). Teknik Dasar Sulaman Pita Untuk Pemula. Yogyakarta: Laksana Transmedia.

Murni, Y., Hirdinis, \& Iqbal, M. A. (2018). Pelatihan Decoupage Bagi Masyarakat Kampung Sawah , Kota Bekasi. Jurnal MITRA, 2(1), 65-76.

Sarno. (2018). Pemberdayaan Kelompok Masyarakat Perajin Bambu Di Desa Sirkandi Purwareja Klampok Banjarnegara. Jurnal Pengabdian \& Pemberdayaan Masyarakat, 2(2), 309317.

Purnomo, H., \& Ferdianto, K., (2009). Desain Sistem Kerja Pada Pengrajin Mendong Dengan Pendekatan Ergonomi Makro.
Prosiding Seminar Nasional Sains Dan Teknologi Ke-2 Tahun 2011 Fakultas Teknik Universitas Wahid Hasyim Semarang, 12-17.

Lita, R.P., Ma'ruf \& Surya, S., (2010). Peningkatan Kualitas Produk Dalam Upaya Mengembangkan Pemasaran Anyaman Pada Sentra Kerajinan Di Kenagarian Kubang, Kabupaten 50 Kota. Artikel Hasil Pengabdian pada Masyarkat, LPPM Unand, 1-7.

Sugita, I. K. G., Priambadi, I. G. N., \& Suarnadwipa. (2016). Pengering Pada Industri Tenun Pewarna Alami Dan Kerajinan Ate Di Desa Seraya Timur Karangasem. Udayana Mengabdi, 15(1), 104-110.

Susilo, Y. S. (2010). Strategi Meningkatkan Daya Saing Umkm Dalam Menghadapi Implementasi Cafta Dan Mea. Buletin Ekonomi Agustus, 8(2), 70-170.

Sachari, A \& Sunarya, Y.Y., (2000). Tinjauan Desain. Bandung: Penerbit ITB. 